\title{
Effect of Genetic Variation on Nausea and Vomiting Treatments Action
}

\section{Bassam Abdul Rasool Hassan*}

Clinical Pharmacy Discipline, School of Pharmaceutical Sciences, University of Sains Malaysia, 11800 Minden, Penang, Malaysia

\section{Nausea and Vomiting Back Ground}

Both nausea and vomiting are recognized as two separate and distinct conditions. Nausea is an unpleasant sensation of being vomit or urge to vomit which may or may not result in vomiting. While, vomiting or emesis is the process of expelling of undigested foods through the mouth. Nausea and vomiting can arises from a different or wide spectrum of etiologies which are either directly associated to cancer disease itself or its treatment. According to the new ranking of chemotherapy side effects, nausea is the number one or the most disturbing side effect while vomiting is the third and sometimes the fifth disturbing chemotherapy side effects [1-6].

\section{Genetic Variation Effect on Nausea and Vomiting Treatments}

Inter individual diversity in drug metabolism is caused by many factors including environmental factors, cultural factors related with type of diet, concomitant drug therapy as well as genetic factors i.e., ethnic variation. All of these variations play an important role in changing pharmacokinetic and pharmacodynamic properties, volume of distribution, elimination, disposition and clinical effect for many drugs $[7,8]$. Much of this distinction has shown to be caused by genetic polymorphisms of the human cytochrome P450 enzymes (CYP) [8]. CYP is the most vital enzymatic system concerned with drug metabolism. Approximately $65 \%$ of common drugs used are metabolized by cytochrome $\mathrm{P} 450$ enzymes and half of them are mediated by the CYP3A subfamily [8]. Depending on this genetic polymorphism will leads to change in the metabolism of antiemetic treatment, this will leads to critical problem mainly within cancer patients since within those patients nausea and vomiting can be clinically significant and severely incapacitating side effects of cytotoxic chemotherapy [9]. These symptoms can symbolize a major therapeutic challenge and if unsatisfactorily controlled by antiemetic treatment, will limit a patient's ability or desire to eat and drink, considerably reduce quality of life, threaten the success of therapy, and result in increased mortality, morbidity, and prominently health care costs [9].

\section{Conclusion}

Therefore it is an obligate matter for each population to develop their own antiemetic treatment guideline depending on the variation in their genes, by this way they can get the maximum benefit of antiemetic treatments and reduce nausea and vomiting negative effect on cancer patients lives. According to that each clinical and medical staff must focus on this point in their future studies.

\section{References}

1. Haggerty M (1999) Nausea and Vomiting. In: Donna O, Christine J, Karen B (Eds) The gale encyclopedia of medicine. Farmington Hills, Gale Research, An International Thomson Company.

2. Coates A, Abraham S, Kaye SB, Sowerbutts T, Frewin C, et al. (1983) On the receiving end--patient perception of the side-effects of cancer chemotherapy Eur J Cancer Clin Oncol 19: 203-208.

3. LeBourgeois JP, McKenna CJ, Coster B, Feyer P, Franzén L, et al. (1999) Efficacy of an ondansetron orally disintegrating tablet: a novel oral formulation of this 5- $\mathrm{HT}(3)$ receptor antagonist in the treatment of fractionated radiotherapyinduced nausea and emesis. Emesis Study Group for the Ondansetron Orally Disintegrating Tablet in Radiotherapy Treatment. Clin Oncol (R Coll Radiol) 11: $340-347$

4. Morrow GR, Hickok JT, Roscore JA, Matteson S (2005) A biobehaviora perspective of nausea and emesis. In: Hesketh PJ (Ed) Management of nausea and vomiting in cancer and cancer treatment. Mississauga, Jones and Barlett.

5. Hesketh PJ (2005) Management of nausea and vomiting in cancer treatment introduction, scope of the problem. In: Hesketh PJ (Ed) Management of nausea and vomiting in cancer and cancer treatment Mississauge, Jones and Bartlett.

6. Rudd JA, Andrews PLR (2005) Mechanisms of acute, delayed and anticipatory emesis induced by anticancer therapies. In: Hesketh PJ (Ed) Management of nausea and vomiting in cancer and cancer treatment Mississauge, Jones and Bartlett.

7. Gross AS, Bridge S, Shenfield GM (1999) Pharmacokinetics of tolbutamide in ethnic Chinese. Br J Clin Pharmacol 47: 151-156.

8. Ruzilawati AB, Suhaimi AW, Gan SH (2007) Genetic polymorphisms of CYP3A4: CYP3A4*18 allele is found in five healthy Malaysian subjects. Clin Chim Acta 383: 158-162

9. Aapro M (2004) Granisetron: an update on its clinical use in the management of nausea and vomiting. Oncologist 9: 673-686.

*Corresponding author: Dr. Bassam Abdul Rasool Hassan, Clinical Pharmacy Discipline, School of Pharmaceutical Sciences, University of Sains Malaysia, 11800 Minden, Penang, Malaysia; Tel: +6-016-423-0950, E-mail: bassamsunny@yahoo.com

Received May 27, 2012; Accepted May 28, 2012; Published May 30, 2012

Citation: Rasool Hassan BA (2012) Effect of Genetic Variation on Nausea and Vomiting Treatments Action. Pharmaceut Anal Acta 3:e111. doi:10.4172/21532435.1000e111

Copyright: (C) 2012 Rasool Hassan BA. This is an open-access article distributed under the terms of the Creative Commons Attribution License, which permits unrestricted use, distribution, and reproduction in any medium, provided the original author and source are credited. 